\title{
Bernhard Witkop A Chemist in a Biomedical Institute
}

Dr. Bernhard Witkop began his impressive scientific career at the Universität München with the Nobel Laureate chemist Heinrich Wieland, where he received his Ph. D. in chemistry in 1940 with a dissertation on phalloidin, a toxic peptide isolated from the deathcap mushroom Amanita phalloides. Witkop's next ten years, seven at München and three at Harvard University, provided important new insights into structures and properties of a variety of indole alkaloids. He also embarked on syntheses of "unnatural" amino acids. Natural products had become an area of research he would enrich throughout his career. After Harvard, he joined the National Institutes of Health (NIH) where his interest in indole alkaloids and amino acids led him to a series of studies on the mechanisms of oxidation of a wide range of organic compounds, including carbazoles and indoles. At NIH, a life-long friendship with the biochemist/pharmacologist Julius Axelrod began in the early fifties with collaborative studies on another indole alkaloid, lysergic acid diethylamide. Another life-long friendship was established at that time with the biochemist/pharmacologist Sindey Udenfriend, beginning with collaborative metabolic studies on 5hydroxytryptophan.

The collaborations at NIH with Axelrod continued with a focus on $O$-methylation of catechol amines, an area of research for which Axelrod was to later receive the Nobel prize. By this time in 1957 Witkop had become chief of the Laboratory of Chemistry, in the National Institute of Arthritis and Metabolic Disease. In 1957, Siro Senoh joined the laboratory as the first of many Japanese scientists to work with Witkop. Dr. Senoh was involved in the collaborations with Axelrod and with Udenfriend on catechol amines and serotonin, including the synthesis and study of the properties of 6-hydroxydopamine and 6-hydroxydopa. Many Japanese scientists joined Witkop's laboratory during the following decades and made major contributions of his research program. Witkop, thus, was closely involved in establishing a tradition of NIH-sponsored fellowships for scientists from abroad, which became the important NIH Visiting 
Program. Witkop during these years became deeply involved with Japanese culture and language, leading to his first lecture in Japanese in Tokyo in 1961. Later, there were lectures in Japanese at Memorial Symposia for Munio Kotake and Shiro Akabori.

In the late fifties, Witkop initiated studies on development of a selective cleavage of peptides using $N$ bromosuccinimide oxidation at tryptophyl residues. The selective cleavage of peptide bonds remained a major interest of Witkop during most of the sixties and led to important, innovative approaches to the study of peptide and protein structure. In addition to cleavage at tyrosinyl and tryptophyl residues with $N$-bromosuccinimide, Witkop working with Erhard Gross developed the cyanogen bromide cleavage of peptides at methionyl residues. This method has enjoyed wide-spread and vital applications in protein chemistry and represents one of many major achievements of Bernhard Witkop.

In the early sixties, Witkop initiated studies on the toxic principles in skin extracts of a frog used to poison blow-darts by Indians in Western Colombia. The active principles, to be named batrachotoxins, proved to be steroidal alkaloids. A pivotal step in the elucidation of the structures of such batrachotoxins was an X-Ray analysis by Isabella Karle of the Naval Research Laboratories. Over the next three decades the investigation initiated by Witkop of alkaloids from frog/toad skin and continued by John Daly of his Laboratory has led to discovery of over 500 novel alkaloids representing at least twenty structural classes. In the early seventies, Witkop established a collaboration with an electrophysiologist Edson Albuquerque of the State University of New York. In their collaborative studies over the next two decades, Albuquerque established the basis for pharmacology/toxicology of the batrachotoxins, histrionicotoxins and pumiliotoxins isolated in Witkop's laboratory from frog skin extracts.

Another interest of Witkop during the sixties was the hydroxyprolines, major constituents of collagen. In collaboration with Udenfriend, Witkop demonstrated that the biosynthetic formation was by hydroxylation of proline residues in collagen. Witkop's interest in prolines continued for many years leading to syntheses of many analogs and to the discovery of a natural dihydroxyproline and a natural cis3,4-methyleneproline. Other areas in which major contributions were made by Witkop and collaborators in the sixties were to the structure elucidation of gramicidins and an auditing of the strucure of ribonuclease. The structure of ribonuclease was the basis for a Nobel Prize in 1971 for Christian Anfinsen of NIH.

The discovery of migration and retention of tritium, deuterium and other substituents during aromatic 
"hydroxylation" by John Daly of Witkop's laboratory and Gordon Guroff of Udenfriend's laboratory in 1966 led to intensive collaborative studies between the two laboratories on this phenomenon, which became known as the "NIH Shift". Such studies culminated in the establishment of arene oxides as key intermediates in monoxygenase-catalyzed formation of phenols. The possible role of arene oxides in toxicity and carcinogenicity of aryl hydrocarbons represented a continuation of such studies, where Donald Jerina, a former member of Witkop's group working on the "NIH-Shift", established bay region diol epoxides as the ultimate carcinogens formed from polycyclic hydrocarbons.

During the seventies Witkop made major contributions to organic photochemistry in studies on photoreductions and/or photocyclizations of nucleoside and nucleotide bases, tryptophans, kynurenic acid, derivatives of tyrosine, tyramine, and catechol amines, mescaline, arene oxides and steroids. He initiated studies with Paul Torrence, a member of his research group, on the synthesis and investigation of polynucleotides as inducers of interferon. These studies ultimately led to the development by Torrence, using a 2',5'-oligoadenylate linked to a deoxyribonucleotide, of a targeted approach for ribonucleasecatalyzed selective destruction of viral RNAs.

In 1969, Bernhard Witkop was elected to the National Academy of Science, one of many honors bestowed on him during his outstanding career. Such honors include the 1958 Hillebrand Award from the American Chemical Society, the Paul Karrer Medal in 1971 and decoration in 1975 by the Emperor of Japan with Kun-Ni-To, the order of the Sacred Treasure. In 1987, Witkop retired as chief of the Laboratory of Chemistry a position he had held for thirty years. On this occasion NIH bestowed upon him the rare title of Institute Scholar and inaugurated for him a Paul Ehrich lecture series that has brought to NIH many illustrious speakers. During his career he provided guidance and direction to scores of postdoctorates, mainly from the United States, Europe and Japan. The list of his "students" is long; only a few have been mentioned in this brief overview. It includes many now renowned scientists. A listing, certainly incomplete, includes chronologically A. Ek, J. B. Patrick, S. M. Goodwin, L. A. Cohen, T. W. Beiler, C. M. Foltz, A. A. Patchett, S. L. Friess, K. Freter, S. Senoh, W. B. Lawson, A. Patchornik, G. F. Holland, G. L. Schmir, L. K. Ramachadran, J. W. Daly, H. Kny, A. V. Robertson, Y. Kanaoka, E. Gross, F. Märki, N. Izumiya, S. Ishii, J. E. Francis, T. Tokuyama, K. Morita, F. Sakiyama, Y. Fujita, R. Sarges, M. Ohno, M. Funatsu, H. Iwasaki, N. Izumiya, P. Cerutti, A. B. Mauger, M. Chaykowsky, T. F. Spande, N. M. Green, T. Yoshida, O. Yonemitsu, J. A. Waters, M. Wilchek, G. W. A. Milne, D. 
M. Jerina, T. Kunieda, Y. Kondo, A. Fontana, P. Torrence, H. C. Ottenheyn, W. Kissing, W. Burgermeister and E. Gössinger. Important collaborators over his career, in addition to Axelrod and Udenfriend, were Edson Albuquerque, Arnold Brossi, K. Freter, F. Irreverre, Yuichi Kanaoka, Isabella Karle, Avram Patchornik and L. K. Ramachadran. All, including myself, owe him a debt of gratitude. His contributions to science as a "chemist in a biomedical institute" are truly far-reaching and display an amazing breadth of interest. This brief summary does not do justice to how his programs have impacted on the fields of chemistry, biochemistry and pharmacology. His creative innovative approach to science has now been turned in retirement to the scholarly analysis of the place of outstanding scientists, such as Paul Ehrlich, Emil Fisher, Heinrich Wieland and his son Theodore, Percy Julian, Munio Kotake and Shiro Akabori, in the history and philosophy of science. His heritage to science lives on and will never cease.
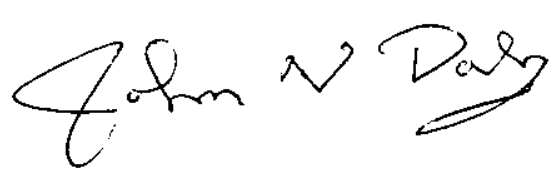

John W. Daly, Ph. D.

Chief, Laboratory of Bioorganic Chemistry NIDDK, NIH 